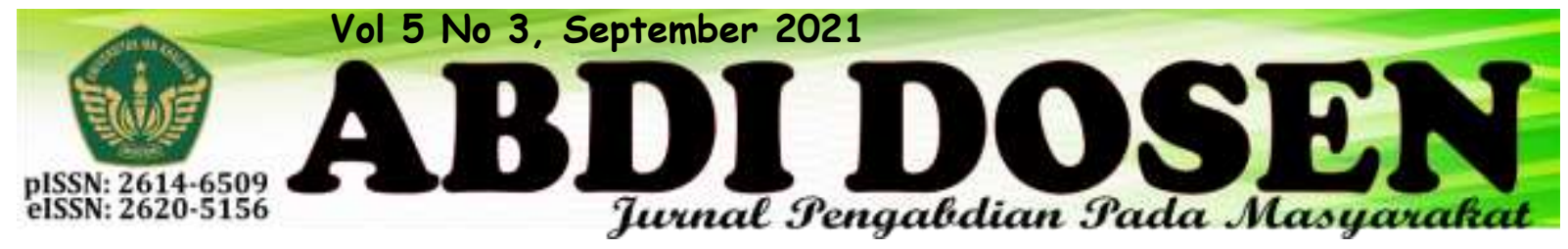

\title{
SOCIOPRENEURSHIP PENGOLAHAN SAMPAH ORGANIK MENJADI PAKAN IKAN DAN PAKAN TERNAK
}

\author{
R. Andi Ahmad Gunadi ${ }^{1}$, Misriandi $^{2}$, Farihen $^{3}$, Nidar Yusuf $^{4}$, Aida Sumardi $^{5}$, Herry \\ Murdiratno $^{6}$ \\ FIP Universitas Muhammadiyah Jakarta ${ }^{1,2,3,4,5,6}$
}

\begin{abstract}
ABSTRAK
Sampah merupakan limbah yang sudah tidak dapat dipakai, memiliki bau aroma yang tidak sedap, dan biasanya dalam kondisi sudah kotor dan keberadaannya sudah tidak pada tempatnya. Dari jenisnya, sampah dapat dibedakan menjadi sampah basah atau organik dan sampah kering atau nonorganik. Sampah basah dan sampah kering saat ini sudah bisa didaur ulang karena mempunyi nilai ekonomis dan merupakan lapangan pekerjaan baru bagi masyarakat. Kita dapat memberikan pembelajaran untuk meningkatkan pemahaman akan manfaat sampah kepada setiap penduduk melalui kegiatan sociopreneurship. Sociopreneurship berasal dari kata social dan enterpreneurship. Sociopreneurship harus dilihat dari makna sosial dan kewirausahaan atau dapat diartikan sebagai kewirausahaan untuk menangani masalahan sosial. Kompetensi dari sociopreneurship adalah bisa membantu mengurangi masalah sosial; Kegiatan sociopreneurship dalam mengolah sampah diharapkan dapat meminimalisir dan meningkatkan pemahaman masyarakat pada sampah menjadi suatu produk yang memiliki manfaat dan mempunyai nilai sosial ekonomi. Target luaran dari kegiatan sociopreneurship pengolahan sampah, untuk jangka pendek adalah masyarakat mengetahui jenis-jenis sampah.
\end{abstract}

Kata Kunci: Sociopreneurship; Masalahan Sosial, Sampah Organik; Pakan Ternak.

\section{PENDAHULUAN}

Sampah merupakan suatu limbah yang sudah tidak dipakai, memiliki bau aroma yang tidak sedap, dan biasanya dalam kondisi sudah kotor dan keberadaannya sudah tidak pada tempatnya. Dari jenisnya, sampah dapat diketahui menjadi sampah basah atau organik dan sampah kering atau nonorganik. Gunadi dan Ansharullah (2019:226). Sampah dengan mudah dapat dijumpai di sekitar lingkungan kehidupan manusia seperti di lingkungan rumah tempat tinggal, di lingkungan sekolah tempat belajar, dan yang pasti di lingkungan sosial masyarakat lainnya.

Standar teknis pengelolaan sampah untuk kawasan pemukiman diatur dalam Standar Nasional Indonesia (SNI) Nomor 3242-2008 tentang Pengelolaan Sampah di Pemukiman dan SNI Nomor 19-24542002 tentang Tata Cara Teknik Operasional Pengelolaan Sampah Perkotaan, kegiatan yang dilaksanakan secara menyeluruh dan terpadu, meliputi: Gunadi dan Aswir. (2018). 
1. Pewadahan

Pewadahan merupakan kegiatan penempatan sampah yang bersifat sementara dalam suatu wadah individual atau komunal di tempat sumber sampah. Tiap rumah minimal memiliki 2 buah tempat sampah untuk memisahkan sampah organik dan anorgaik.

2. Pengumpulan

Pengumpulan sampah merupakan kegiatan penanganan yang tidak hanya mengumpulkan sampah dari wadah individual dan atau wadah komunal, melainkan juga mengangkutnya ke terminal tertentu. Pola pengumpulan sampah dibedakan menjadi empat pola, yaitu:

a) Pola individual tidak langsung, dari rumah ke rumah.

b) Pola individual langsung, dengan truk untuk jalan dan fasilitas umum.

c) Pola komunal langsung untuk pasar dan daerah komersial.

d) Pola komunal tidak langsung untuk permukiman padat.

3. Pengolahan dan daur ulang di sumber dan TPS

Mekanisme pengelolaan dan daur ulang sampah di sumber dan TPS dapat dilakukan dengan cara:

a) Pembuatan kompos skala rumah tangga dan daur ulang sampah anorganik, sesuai dengan tipe rumah atau luas halaman yang ada.

b) Penbuatan kompos skala lingkungan di TPS

c) Daur ulang sampah anorganik di TPS.

4. Pemindahan

Pemindahan sampah adalah proses memindahkan sampah hasil pengumpulan ke dalam alat pengangkut untuk dibawa ke tempat pembuangan akhir.

5. Pengangkutan

Pengangkutan adalah kegiatan pengangkutan sampah dari TPS atau wadah komunal ke TPST atau TPA dengan frekuensi pengangkutan disesuaikan dengan jumlah sampah yang ada. Pengangkutan sampah residu dari TPS atau wadah komunal dilakukan bila kontainer telah penuh dan sesuai jadwal pengangkutan yang telah dikonfirmasikan dengan pengelola sampah kota. Menurut SNI 19-2454-2002 terdapat tiga metode pembuangan akhir yang dapat dilakukan pada TPST atau TPA yaitu:
a) Penimbunan
terkendali (controlled landfill) dilengkapi pengolahan dan gas.
b) Lahan urug saniter (sanitary landfill) dilengkapi pengolahan dan gas.
c) Penimbunan dengan sistem kolam (fakultatif, maturasi) untuk daerah pasang surut.

Dalam kegiatan yang dilakukan setiap hari setiap manusia akan menghasilkan sampah yang dapat dikatagorikan sebagai sampah organik dan sampah nonorganik. Sampah organik merupakan sampah yang bisa diurai, seperti bekas makanan yang tersisa, daundaun, ranting dan dahan dari pohon yang ada di halaman rumah, dan sebagainya. Sedangkan sampah nonorganik merupakan sampah yang tidak bisa di urai tetapi bisa diolah atau diproses kembali misalnya plastik, kaca, dan sebagainya. Sampah jenis ini jika tidak diolah dengan baik, dapat menimbulkan bencana bagi 
manusia dan lingkungan hidup. Widawati dkk, (2014-119).

Sampah organik dan nonorganik merupakan sesuatu yang dapat menghasilkan uang yang diabaikan karena masyarakat tidak memahami dan tidak bisa mengolahnya dengan alasan tidak bersih, tidak sehat dan memiliki aroma yang tidak nyaman. Untuk sampah nonorganik, terdapat beberapa jenis yang hanya dapat didaur ulang 1-2 kali, tetapi pada prinsipnya sampah nonorganik seperti sampah plastik tidak bisa diolah kembali lebih dari dua kali pengolahan karena dapat menimbulkan bahaya untuk kesehatan.

Pengelolaan sampah yang selama ini sudah banyak dilakukan masyarakat adalah dengan konsep 4R, yaitu Reduce (Mengurangi), Reuse (Memakai kembali), Recycle (Mendaur ulang); dan Replace (Mengganti). Konsep 4R ini bertujuan meminimalkan penggunaan produk sampah nonorganik dari sumbernya, sehingga hasilnya dapat memperkecil pencemaran lingkungan dan kesehatan, menghasilkan banyak kegunaan untuk masyarakat, dan dapat mengubah pandangan negatif masyarakat terhadap sampah. (Marliani 2014:124-132). Keberhasilan pengelolaan sampah dengan konsep 4R sangat dipengaruhi oleh keterlibatan langsung masyarakat yang dengan secara sadar seharusnya mau mengubah aspek kognitif, afektif, psikomotorik, dan kebiasaan yang ada yang masih mengikuti tata cara norma sosial budaya dan sosial ekonomi yang berlaku pada lingkungan masyarakat tempat tinggalnya. Puspitawati dan Mardwi, 2012:350.

Pengelolaan sampah dengan konsep 4R bertujuan untuk membatasi masyarakat menggunakan barang yang bahan dasarnya terbuat dari plastik, yaitu: dalam kehidupan sehari-hari bersedia menggunakan suatu barang atau produk hingga beberapa kali; membatasi dan mengurangi pembelian dan pemakaian barang atau produk yang terbuat dari plastik; dan suatu saat dapat menggunakan dan memanfaatkan kembali produk-produk yang terbuat dari produk bukan plastik. Kelemahan program 4R, Reduce (Mengurangi); sebisa mungkin melakukan pengurangan penggunaan barang atau material dari produk yang terbuat dari plastik. Semakin banyak kita menggunakan material, semakin banyak sampah yang dihasilkan. Reuse (Memakai kembali); sebisa mungkin pilihlah barang yang bisa dipakai kembali. Hindari pemakaian barang yang disposable (sekali pakai, buang). Hal ini dapat memperpanjang waktu pemakaian barang sebelum menjadi sampah. Recycle (Mendaur ulang); sebisa mungkin barang-barang yg sudah tidak berguna dapat didaur ulang. Tidak semua barang bisa didaur ulang, namun saat ini sudah banyak industri non-formal dan industri rumah tangga yang memanfaatkan sampah menjadi barang lain. Teknologi daur ulang, khususnya bagi sampah plastik, sampah kaca, dan sampah logam, merupakan suatu jawaban atas upaya memaksimalkan material setelah menjadi sampah, untuk dikembalikan lagi dalam siklus daur ulang material tersebut. Replace (Mengganti); teliti barang yang kita pakai sehari-hari. Gantilah barang barang yang hanya bisa dipakai sekalai dengan barang yang lebih tahan lama. Juga teliti agar hanya memakai barang-barang yang lebih ramah lingkungan, contohnya ganti pemakaian kantong keresek dengan tas dan jangan gunakan styrofoam karena 
kedua produk ini tidak bisa di degradasi secara alami.

Saat ini konsep pengolahan sampah ini oleh Kelompok Swadaya Masyarakat Tempat Pembuangan Sampah Terkhir Reduce (Mengurangi), Reuse (Memakai kembali), Recycle (Mendaur ulang) atau disingkat TPS3R sudah dimanfaatkan dan memiliki nilai ekonomis yang cukup baik dan dapat menjadi lapangan pekerjaan baru. TPS3R berpendapat dengan mengetahui jenis sampah diharapkan bisa berkembang menjadi sebuah pemahaman bahwa berbagai sampah yang dihasilkan masyarakat dan terdapat di lingkungan masyarakat tidak harus berkonotasi dengan sesuatu yang tidak baik atau negatif. Dengan mengetahui karakteristik sampah, TPS3R dapat mengolah sampah dengan baik, benar dan tepat yang secara ekonomis sangat menguntungkan karena dapat menghasilkan tambahan penghasilan. Sampah organik yang biasanya diolah menjadi pupuk kompos untuk tanaman, saat ini melalui cara yang sederhana, sudah dapat pula diolah menjadi pakan ternak dan pakan ikan.

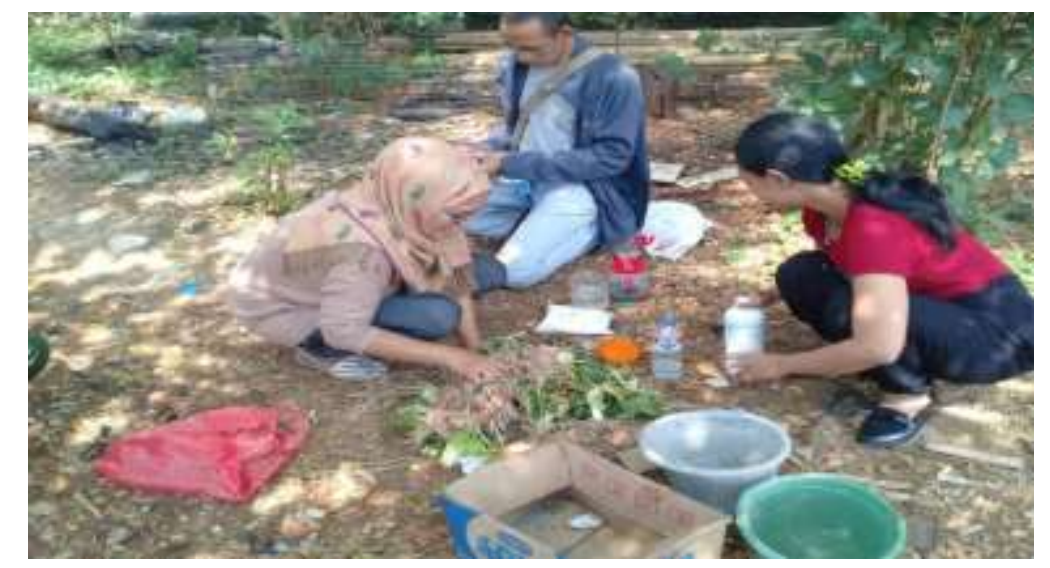

Gambar 1. Kegiatan pengelolaan sampah di TPST 3R Pasar Ciputat

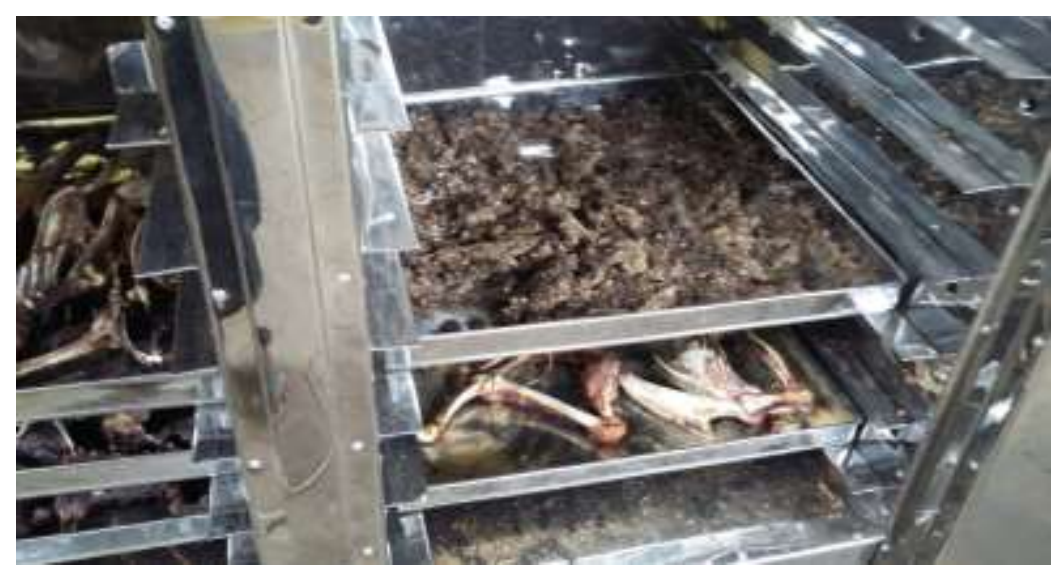

Gambar 2. Sampah organik yang akan diolah menjadi pakan ikan dan pakan ternak di TPST 3R Pasar Ciputat

\section{Solusi Permasalahan}

Sampah organik biasanya banyak berasal dari pemukiman masyarakat. Sampah organik ini sebenarnya sumber uang yang diabaikan karena masyarakat belum paham atau tidak mau mengolah sampah organik dengan alasan kotor dan memiliki aroma bau yang menyengat. 
Selain jenis limbah organik basah dan limbah organik kering, limbah yang berasal dari pemukiman penduduk ini juga mengandung limbah anorganik yang dapat di daur ulang. Bagi beberapa orang limbah anorganik dapat dimanfaatkan dan bernilai ekonomis sehingga dapat menjadi lapangan kerja baru. Apabila tidak dimanfaatkan, sampah yang sudah berada di lokasi TPA biasanya dibiarkan tertimbun dan mengalami proses dekomposisi secara perlahan-lahan.

Selain biasa digunakan sebagai bahan pengisi untuk menguruk, sampah juga biasanya dibakar sehingga asap yang dihasilkan biasanya mengganggu masyarakat. Kegiatan di tempat pembuangan sampah pun belum sepenuhnya optimal karena sebagian besar masyarakat belum memahami peran mikroorganisme dekomposisi sebagai pengurai sampah. Sampah atau limbah dapat menjadi rejeki bagi para pengelola sampah jenis organik. Karena itu pengenalan mikroorganisme untuk mengurai dan mengolah sampah perlu disosialisasikan kepada masyarakat, terutama bagi penduduk yang tinggal di wilayah area tempat buang limbah.

Sociopreneurship solusi permasalahan sampah:

1. Pengelolaan Sampah. Aktivitas yang dapat dilakukan:

a. Pencegahan dan pengurangan limbah dari rumah-rumah yang ada di wilayah pemukiman penduduk. Aktivitas yang dapat dilakukan adalah di setiap rumah limbah tersebut sudah dipilah dan dipisah menurut jenis limbah, yaitu jenis limbah organik dan limbah anorganik dengan menyiapkan tempat pembuangan sampah untuk jenis limbah organik dan limbah anorganik.

b. Memanfaatkan kembali sampah, terdiri dari:

1) Memanfaatkan sampah organik, untuk composting (pengomposan). Sampah organik mudah membusuk dan hal ini dapat dimanfaatkan kembali menjadi pupuk kompos yang bersifat bersahabat dengan lingkungan.

2) Memanfaatkan sampah anorganik secara langsung atau tidak langsung. Pemanfaatan secara langsung, misalnya membuat kerajinan berbahan baku barang bekas, atau kertas daur ulang. Memanfaatkan kembali secara tidak langsung contohnya menjual barang bekas seperti kertas, plastik, kaleng, koran bekas, botol, gelas dan botol air minum dalam kemasan.

c. Tempat Pembuangan Sampah Akhir

Dengan kemampuan mengelola sampah secara baik dan benar, sisa sampah akhir yang betulbetul sudah tidak dapat dimanfaatkan kembali ada sekitar sepuluh persen. Aktivitas ini tentu saja dapat menurunkan biaya pengangkutan sampah oleh pengelola kawasan, mengurangi luas lahan yang dibutuhkan sebagai tempat untuk lokasi TPS, serta mengurangi masalah yang ditimbulkan oleh sampah yang 
saat ini banyak menjadi masalah bagi banyak pemerintah daerah.

d. Konsep 4R yang bisa diterapkan pada kegiatan mengelola sampah:

1) Reduce (mengurangi); mengurangi pemakaian barang atau produk. Semakin banyak menggunakan barang atau produk, semakin banyak sampah yang dihasilkan.

2) Reuse (memakai kembali); pilihlah sampah yang bisa digunakan kembali. Hindari pemakaian barang atau produk yang disposable (sekali pakai, buang). Hal ini dapat memperpanjang waktu pemakaian barang sebelum menjadi sampah.

3) Recycle (mendaur ulang); Tidak semua barang bisa didaur ulang, namun saat ini sudah banyak industri nonformal dan industri rumah tangga yang memanfaatkan sampah menjadi barang lain. Teknologi daur ulang, khususnya bagi sampah plastik, sampah kaca, dan sampah logam, merupakan suatu jawaban atas upaya memaksimalkan produk setelah menjadi sampah, untuk dikembalikan lagi dalam siklus daur ulang produk.

4) Replace (mengganti); Gantilah pemakaian produk yang hanya dapat dipakai sekali dengan produk yang pemakaiannya dapat bertahan lebih lama. Pakailah produk yang ramah lingkungan, Misalnya, ganti kantong keresek dengan keranjang bila berbelanja, dan jangan pergunakan styrofoam karena kedua bahan ini tidak bisa didegradasi secara alami.

2. Pengolahan Sampah.

Melalui kegiatan sociopreneurship dengan cara yang sederhana, sampah jenis organik akan diolah menjadi pakan ternak dan pakan ikan yang secara ekonomis dapat menghasilkan pendapatan bagi yang mengolahnya.

Sampah pada dasarnya mengandung potensi yang dapat dikembangkan menjadi produk bernilai ekonomis. Dari setiap meter kubik sampah yang berasal dari wilayah pemukiman, dengan berat sekitar 120-170 kg, dapat dipastikan tujuh puluh persen diantaranya merupakan sampah organik jenis daun-daunan, ranting dan sisa-sisa makanan dan sayuran yang dapat diproses kembali menjadi pupuk kompos. Sisanya sejumlah tiga puluh persen berupa sampah anorganik yang terdiri dari jenis sampah logam, plastik, kertas, serta barang pecah belah yang dapat didaur ulang menjadi berbagai produk yang berharga.

\section{Gambaran Iptek Pengolahan Sampah Organik menjadi Pakan Ternak dan Pakan Ikan}

Membuat pakan dari sampah dimulai dengan pemisahan sampah organik dan anorganik, dilanjutkan dengan pencacahan, fermentasi pengeringan, penepungan, pencampuran, dan pembuatan pelet. Pemisahan sampah organik dari sampah nonorganik dimaksudkan agar sampah yang diolah hanya yang dapat dicerna oleh ternak 
serta menghindarkan ternak dari mengonsumsi bahan-bahan beracun atau yang mengandung logam berat. Pemisahan sebaiknya dapat dilakukan di tingkat produsen sampah (pasar atau rumah tangga). Oleh karena itu, untuk program massal perlu disediakan tempat sampah organik dan anorganik di tingkat produsen sampah. Sampah dari rumah sakit dan pabrik yang banyak mengandung logam berat atau bahan beracun seyogianya dihindari.

Sampah organik yang telah terpisah dari bahan lain selanjutnya dicacah dengan alat atau mesin pencacah agar bentuknya lebih kecil dan untuk memudahkan fermentasi. Fermentasi dimaksudkan untuk meningkatkan kandungan gizi dan nilai cerna sampah karena kandungan gizi sampah umumnya rendah tetapi serat kasarnya relatif tinggi. Fermentasi dilakukan dengan menggunakan inokulan bakteri dan cara yang tepat agar diperoleh produk yang bermutu tinggi.

Setelah difermentasi, sampah dikeringkan dengan cara dijemur, lalu digiling hingga menjadi tepung. Selanjutnya tepung sampah ditambah bahan lain termasuk enzim dan diaduk dalam mesin pencampur, sehingga diperoleh pakan komplit yang sesuai dengan kebutuhan ternak. Apabila diperlukan, semua bahan yang sudah tercampur dibentuk pelet. Pelet pakan ternak dapat disimpan hingga 6 bulan. Idealnya ransum komplit diberikan sekitar tiga persen dari bobot hidup ternak per hari. Dengan jumlah pakan tersebut, sapi tidak lagi memerlukan HMT atau rumput. Namun sebagian petani ternyata masih memberikan rumput. Sebagai contoh, jika ternak diberi pakan komplit satu koma lima persen dari bobot hidup per hari, peternak tinggal memberi rumput lima puluh persen dari kebutuhan semestinya.

Penggunaan pakan komplit berbahan baku sampah sebanyak satu koma lima persen dari bobot badan sapi selama lima bulan, memberikan pertambahan bobot badan rata-rata enam ratus gram per hari. Secara ekonomis pemanfaatan sampah untuk pakan ini sangat prospektif mengingat bahan dan biaya produksinya relatif murah, sedangkan efeknya terhadap pertumbuhan sapi cukup baik. Berdasarkan analisis ekonomi, penggemukan sapi dengan ransum komplit berbahan baku sampah memberikan keuntungan sampai dua ratus persen dibandingkan dengan cara tradisional. Dampak positif lainnya adalah bisa menjadi peluang usaha dan menyerap banyak tenaga kerja.

Pakan ternak buatan ini tanpa tambahan vitamin dan konsentrat sebagai perangsang pertumbuhan. Semua bahan bakunya organik. Meski dari bahan baku limbah makanan, pakan ternak ini aman. Di dalam pelet terdapat kandungan protein sekitar tiga puluh persen. Selain itu, tidak ditemukan unsur merkuri, boraks, formalin atau zat berbahaya lainnya bagi kesehatan.

Untuk membuat cairan probiotik, kita dapat memanfaatkan limbah minuman kemasan. Pembuatan probiotik dengan metode mikroorganisme lokal (MOL) dibuat dengan memanfaatkan sampah segala jenis buah-buahan, kecap, minuman sari buah, susu, dan yougurt yang sudah kedaluwarsa. Semua bahan MOL dicampur dan dimasukkan dalam wadah khusus kemudian difermentasi selama dua puluh satu hari agar menjadi probiotik cair. Sampai sekarang formula 
ini tetap dapat digunakan dan tak pernah kehabisan karena bahan baku banyak tersedia

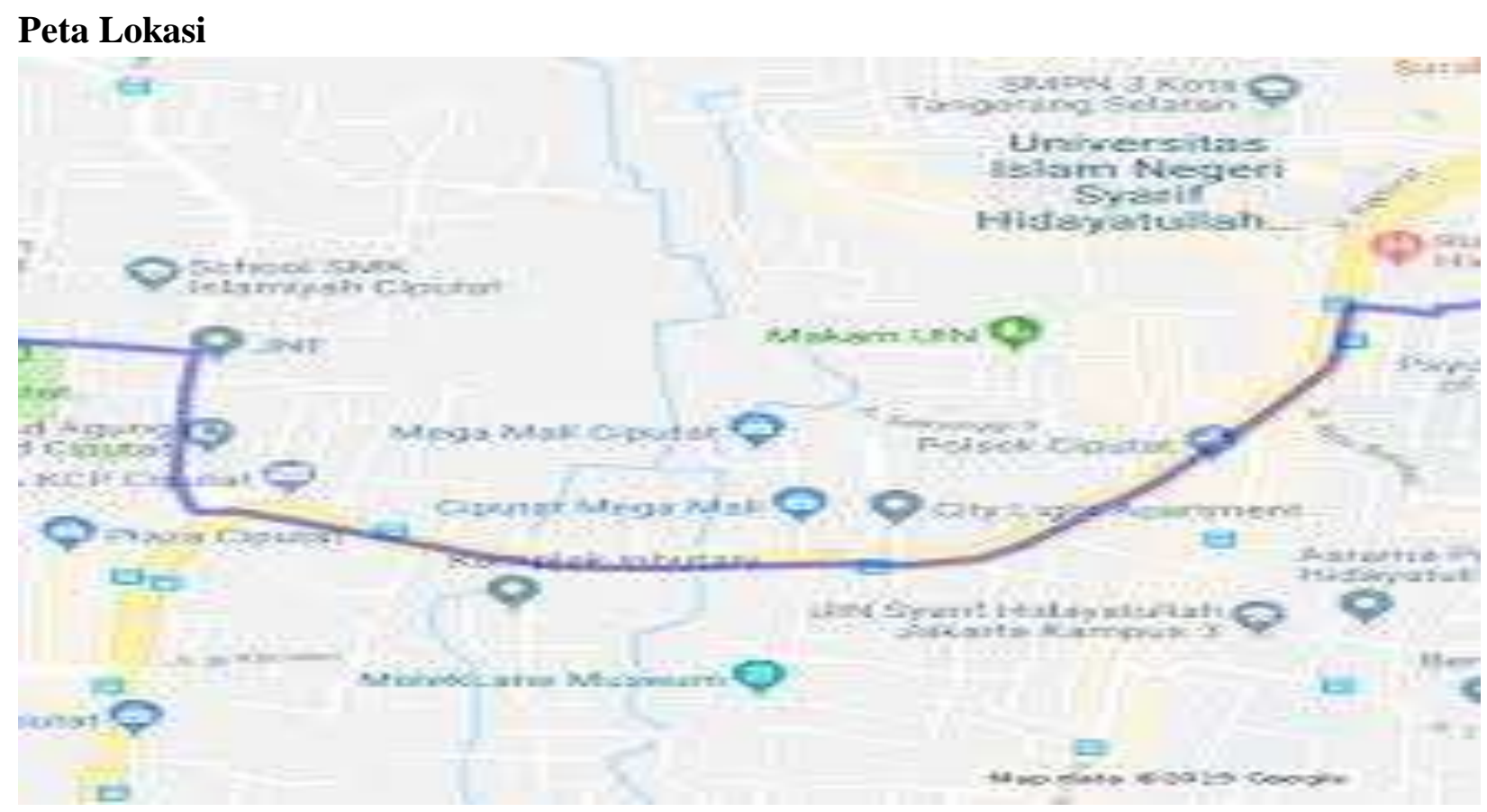

Sumber: google maps

Gambar 2. Peta Lokasi

\section{METODE PELAKSANAAN}

1. Nama kegiatan: Sociopreneurship Pengolahan Sampah Organik Menjadi Pakan Ternak dan Pakan Ikan. Dengan mengetahui karakteristik sampah, kita dapat mengolah sampah dengan baik, benar dan tepat yang secara ekonomis sangat menguntungkan karena dapat menghasilkan tambahan penghasilan. Sampah organik yang biasanya diolah menjadi pupuk kompos untuk tanaman. Kini melalui cara yang sederhana, sampah organik dapat pula diolah menjadi pakan ternak dan pakan ikan.

\section{Tempat dan waktu kegiatan}

Tempat: Pasar Ciputat, Kelurahan Ciputat Tangerang Selatan
Waktu Kegiatan: Februari September 2021

3. Peserta kegiatan, dalam hal ini disebut sebagai kelompok sasaran Pada kegiatan Pengabdian Masyarakat ini yang menjadi kelompok sasaran adalah masyarakat yang tinggal di wilayah pasar Ciputat Tangerang Selatan.

\section{Tujuan dan Manfaat}

Tujuan dari kegiatan Pengabdian Masyarakat adalah:

a. Meningkatkan kapasitas masya rakat dalam mengolah sampah organik sebagai kegiatan yang dilakukan bersama-sama dan dapat 
menghasilkan tambahan penda patan

b. Masyarakat dapat termotivasi mengolah sampah organik yang ada di TPA pasar Ciputat menjadi sampah yang ramah lingkungan dan bernilai ekonomis, sehingga diharapkan bukan hanya dapat mengurangi dampak bahaya sampah bagi kesehatan dan lingkungan, juga dapat membantu perekonomian masyarakat sekitar.

c. Masyarakat dapat lebih produktif untuk menangani masalah sampah yang ada di lingkungannya sebagai sebuah peluang bisnis yg bernilai ekonomis.

Manfaat

Menambah wawasan pengetahuan dan keterampilan masyarakat dalam mengolah sampah organik yang ramah lingkungan dan bernilai ekonomis.

\section{Target kegiatan}

Kegiatan Pengabdian Masyarakat secara urgensi memberikan solusi jangka pendek pemahaman masyarakat dalam mengolah sampah organik pasar Ciputat, Tangerang Selatun. Tujuan jangka pendek masyarakat dapat mengurangi dampak bahaya sampah bagi kesehatan dan lingkungan. Tujuan jangka panjang masyarakat termotivasi untuk mengolah sampah organik menjadi pakan ternak dan pakan ikan yang bernilai ekonomis dan menjadi peluang binis yang menjanjikan.

\section{Khalayak Sasaran}

Khalayak sasaran kegiatan Pengabdian Masyarakat adalah masyarakat
Kelurahan Ciputat, Tangerang Selatan yang tinggal di lingkungan pasar, terdiri dari perorangan individu, kelompok sosial atau kelompok komunitas, lembaga-lembaga yang ada di lingkungan masyarakat yang mempunyai kepentingan terhadap situasi dan kondisi, masyarakat pada tempat pembuangan akhir sampah.

\section{Metode Pelaksanaan}

Metode yang digunakan dalam kegiatan Pengabdian Masyarakat lebih bersifat informatif dan persuasif terdiri dari beberapa tahapan yang diawali dengan pendekatan personal, diskusi dan praktik atau simulasi. Tahapan pada kegiatan ini terdiri dari:

Tahap Persiapan.

Kegiatan yang dilakukan adalah mengurus perijinan, observasi, wawancara dan studi dokumentasi untuk mengetahui:

a. Kondisi Sarana dan Prasarana TPA Pasar Ciputat

b. Data jumlah/volume sampah perhari, perminggu dan perbulan TPA Pasar Ciputat

c. Data jumlah pedagang dan pengguna TPA Pasar Ciputat perhari, perminggu dan perbulan

d. Data jumlah tenaga kebersihan TPA Pasar Ciputat

e. Data pengelolaan dan pengolahan sampah TPA Pasar Ciputat

f. Data konsumen dan calon konsumen pakan ikan/ternak

g. Data kompetitor produk pakan ikan/ternak

Tahap Pelaksanaan.

Pada tahap ini kegiatan yang dilakukan adalah: 
a. Sosialisasi pengelolaan sampah organik dan non organik bagi kesehatan dan lingkungan

b. Studi banding pengolahan pupuk kompos dan pakan ikan/ternak

c. Pengolahan sampah organik menjadi pakan ikan dan pakan ternak

d. Evaluasi pengolahan pakan ikan dan pakan ternak

Tahap Pendampingan

Pada tahap ini kegiatan yang dilakukan adalah melakukan pendampingan kepada setiap individu, kelompok dan atau lembaga yang terlibat pada kegiatan Pengabdian Masyarakat pengolahan sampah organik menjadi pakan ikan/ternak. Pada tahap ini juga dilukan kegiatan monitoring dan evaluasi pada setiap kegiatan yang dilakukan khalayak sasaran.

Tahap Keberhasilan

Setiap kegiatan tentunya harus memiliki tujuan dan manfaat, demikian juga dalam kegiatan Pengabdian Masyarakat ini memiliki dan tujuan dan manfaat yang perlu untuk diwujudkan melalui tahapan dan proses yang sistematis dan terukur. Adapun indikator keberhasilan kegiatan adalah:

1. Khalayak sasaran mengetahui jenis-jenis sampah organik dan nonorganik.

2. Khalayak sasaran mampu mengelola dan mengolah sampah organik dan nonorganik

3. Khalayak sasaran mampu mengolah sampah organik menjadi pakan ikan dan pakan ternak yang bermanfaat dan bernilai ekonomis.

4. Khalayak sasaran mampu memproduksi pakan ikan dan pakan ternak secara mandiri

5. Khalayak sasaran mampu memasarkan pakan ikan dan ternak di kios dan atau di koperasi pasar

6. Tim pengabdian berhasil menulis artikel dan dipublikasikan pada jurnal dan kegiatan seminar yang bersifat nasional ataupun internasional.

\section{Kegiatan Pelatihan}

Tahapan berikutnya adalah kegiatan pelatihaan dengan judul: Sociopreneurship Pengolahan Sampah Oganik menjadi Pakan Ikan dan pakan Ternak. Sesuai dengan tujuan awal, kegiatan Pengabdian Masyarakat ini dimaksudkan untuk:

a. Meningkatkan kapasitas masy arakat dalam mengelola sampah organik yang berasal dari sampah rumah tangga, lingkungan tempat tinggal dan atau hasil industri jasa lainnya yang ada di TPA Pasar Ciputat

b. Memotivasi masyarakat untuk mengolah sampah organik menjadi sampah yang ramah lingkungan dan bernilai ekonomis, sehingga diharapkan bukan hanya mengurangi dampak pencemaran lingkungan, melainkan juga dapat membantu perekonomian mas yarakat sekitar.

c. Masyarakat diharapkan dapat lebih produktif untuk menangani masalah sampah organik yang ada di lingkungan tempat tinggalnya sebagai sebuah peluang usaha yang bernilai ekonomis. 
9. Materi Kegiatan Pelatihan:

Pengolahan Sampah Organik menjadi

Pakan Ikan dan Pakan Ternak

Sebagai wujud kepedulian

lingkungan kita mencoba

mengolah sampah organik menjadi

pakan ternak dan pakan ikan.

Membuat pakan dari sampah di mulai dengan pemisahan sampah organik dan nonorganik, dilanjutkan dengan pencacahan, fermentasi, pengeringan, penepu ngan, pencampuran, dan pembuatan pelet. Pemisahan sampah organik dari sampah nonorganik dimaksudkan agar sampah yang diolah hanya yang dapat dicerna oleh ternak/ikan serta menghindarkan ternak/ikan dari mengkonsumsi bahan-bahan beracun atau yang mengandung logam berat. Pemisahan sebaiknya dapat dilakukan di tingkat produsen sampah (pasar atau rumah tangga). Oleh karena itu, untuk program massal perlu disediakan tempat sampah organik dan nonorganik di tingkat produsen sampah. Sampah dari rumah sakit dan pabrik yang banyak mengandung logam berat atau bahan beracun seyogianya dihindari. Sampah organik yang telah terpisah dari bahan lain selanjutnya dicacah dengan alat atau mesin pencacah agar bentuknya lebih kecil dan untuk memudahkan fermentasi.

Fermentasi dimaksudkan untuk meningkatkan kandungan gizi dan nilai cerna sampah karena kandungan gizi sampah umumnya rendah tetapi serat kasarnya relatif tinggi. Fermentasi dilakukan dengan menggunakan inokulan bakteri dan cara yang tepat agar diperoleh produk yang bermutu tinggi. Setelah difermentasi, sampah dikeringkan dengan dijemur lalu digiling hingga menjadi tepung. Selanjutnya tepung sampah ditambah bahan lain termasuk enzim dan diaduk dalam mesin pencampur, sehingga diperoleh pakan komplit yang sesuai dengan kebutuhan ternak. Apabila diperlukan, semua bahan yang sudah tercampur dibentuk pelet. Pelet pakan ternak dapat disimpan hingga 6 bulan. Idealnya ransum komplit diberikan sekitar tiga persen dari bobot hidup ternak per hari. Dengan jumlah pakan tersebut, sapi tidak lagi memerlukan HMT atau rumput. Namun sebagian petani ternyata masih memberikan rumput. Sebagai contoh, jika ternak diberi pakan komplit setengah persen dari bobot hidup per hari, peternak tinggal memberi rumput lima puluh persen dari kebutuhan semestinya.

Keuntungan Ekonomi

Penggunaan pakan komplit berbahan baku sampah organik sebanyak satu setengah persen dari bobot badan pada sapi selama lima bulan, memberikan pertambahan bobot badan rata-rata $650 \mathrm{~g} / \mathrm{hari}$. Secara ekonomis pemanfaatan sampah untuk pakan ini sangat prospektif mengingat bahan dan biaya produksinya relatif murah, sedangkan efeknya terhadap pertumbuhan sapi cukup baik. Berdasarkan analisis ekonomi, penggemukan sapi 
dengan ransum komplit berbahan baku sampah memberikan keuntungan sekitar dua ratus persen dibandingkan dengan cara tradisional.

\section{Rencana Keberlanjutan Program}

Merujuk pada hasil kegiatan yang akan dilakukan, terutama kegiatan pelatihan mengenai pengolahan sampah organik, maka diharapkan untuk selanjutnya diperlukan kegiatan pendampingan bagi keberlanjutan pengelolaan sampah ini, yaitu memberikan nama atau merek untuk produk pakan ternak dan pakan ikan agar dapat mempermudah dalam

\section{DAFTAR PUSTAKA}

Londra, Made, 2017:1. Balai Pengkajian Teknologi Pertanian Bali. 2018. Sampah untuk Pakan Ternak https://agromedia.net/mengolahlimbah-organik-menjadi-pakan-danpupuk-2/

Dadan M. Ramdan. 2017. Begini cara mengubah sampah jadi pakan ikan https://peluangusaha.kontan.co.id/ne ws/begini-cara-mengubah-sampahjadi-pakan-ikanDinas Lingkungan Hidup Pemerintah Provinsi DKI $\underline{\text { Jakarta }}$

Gunadi, R. Andi Ahmad dan Ansharullah, (2019:226).

Pengetahuan Pengelolaan Sampah sebagai Sumber Belajar Pendidikan Karakter Siswa SD Menurut Perspektif Islam, Jurnal Misykat AlAnwar Vol 30, No 2 (2019) ISSN (print) 0854-6460(online) 2502-2970. pemasarannya. Pemberian nama produk atau merek ini harus ijin dan terdaftar pada lembaga pemerintah yang berwenang.

Pendampingan dilakukan untuk meningkatkan kreativitas dalam mengolah sampah baik dalam jenis produksi maupun kemasan/hasil dari produksi tersebut dan proses pemasaran produk. Kegiatan ini dapat dilaksanakan dengan kegiatan penguatan kelompok usaha yang diadakan atas dasar kerjasama pelatihan di koperasi desa, misalnya, guna terjalinnya kerjasama kelembagaan pemerintah dengan masyarakat setempat.

DOI:10.31904/ma.v30i2.4308 https://jurnal.umj.ac.id/index.php/Ma A16/issue/view/336/showToc

Gunadi, R. Andi Ahmad. dan Aswir. (2018). Pemanfaatan Sampah sebagai Sumber Belajar Siswa SD. Jakarta: UMJ Press. ISBN: 9786025272660

Marliani, Novi. Pemanfaatan Limbah Rumah Tangga (Sampah Anorganik) sebagai Bentuk Implementasi dari Pendidikan Lingkungan Hidup. Jurnal Formatif 4(2):124-132, 2014 http://journal.lppmunindra.ac.id/inde x.php/Formatif/article/download/146 $\underline{140}$.

Mulyono (2017:6). Membuat Mikroorgani sme Lokal (MOL) dan Kompos dari Sampah Rumah Tangga. Jakarta: PT AgroMedia Pustaka. 
Widawati, Enny. Harliantotanudjaja, Iskandar, Isdaryanto. Budiono, Carlos. Kajian Potensi Pengolahan Sampah (Studi Kasus: Kampung Banjarsari). Jurnal Metris, 15, 2014. ojs.atmajaya.ac.id/index.php/metris. 2014:119. 